\title{
Design and Development of Groundnut Planter for Power Weeder
}

\author{
A. Anil Kumar*, Ch. Ramulu, B. Laxman and G. Kishore \\ College of Agricultural Engineering (ANGRAU), Madakasira, Andhra Pardesh-515301, India \\ *Corresponding author
}

\section{A B S T R A C T}

\begin{tabular}{|l|}
\hline Ke y w o r d s \\
Groundnut planter, \\
Power weeder, \\
Positive draft, \\
Negative draft
\end{tabular}

Groundnut is the sixth most important oilseed crop in the world. The technology constitute one of the major solutions to low productivity and the expansion of the production area associated with traditional hand tools used by the rural farmers The planting operation is one of the most important cultural practices associated with crop production. The basic idea for mounting of groundnut planter to the power weeder is "the negative draft generation of the power weeder helps to reduce the positive draft requirement of groundnut planter". The row to row spacing was also measured at different locations; it was observed that $30 \mathrm{~cm}$ spacing between two rows throughout the field. The depth and width of furrow opener was measured under field condition. It was observed that, the average width and depth of furrow opener was $10 \mathrm{~cm}$ and $5 \mathrm{~cm}$ respectively for entire row. Developed power weeder drawn groundnut planter consists of one ground wheels of diameter $38.12 \mathrm{~cm}$, three no. of plates provided mounted on the rotating shaft. The entire attachment was fixed on the frame. Ground wheel rotates the power transmit with the suitable gears and chain and rotate metering unit ( 3 plates) with attached spoons. Total length of the machine $1.2 \mathrm{~m}$ and width is $90 \mathrm{~cm}$.

\section{Introduction}

Groundnut is the sixth most important oilseed crop in the world. The major groundnut producing countries in the world are India, China, Nigeria, Senegal, Sudan, Burma and the United States of America. It contains 48$50 \%$ oil and $26-28 \%$ protein, and is a rich source of dietary fiber, minerals, and vitamins. India is one of the largest producers of oilseeds in the world and occupies an important position in the Indian agricultural economy. It is estimated that nine oilseeds namely groundnut, rapeseed-mustard, soybean, sunflower, safflower, sesame, Niger, castor and linseed, accounted for an area of 4.19 Million hectares with the production of 5.62 Million tonnes (2011-2012). Groundnut is called as the 'King' of oilseeds. It is one of the most important food and cash crops of our country.

The Kharif crop is sown with a seed drill or with a suitable planter at a depth of $8-10 \mathrm{~cm}$. the spacing between the adjacent rows varies from $30-60 \mathrm{~cm}$ and within the row from 10-15 $\mathrm{cm}$. the inter-row spacing varies between 20 and $30 \mathrm{~cm}$ and the intra-row spacing between 10 and $20 \mathrm{~cm}$.

The technology constitute one of the major solutions to low productivity and the expansion of the production area associated with traditional hand tools used by the rural 
farmers (Mekki and Mohamed, 2011). The planting operation is one of the most important cultural practices associated with crop production.

Increases in crop yield, cropping reliability, cropping frequency and crop returns all depend on the uniform and timely establishment of optimum plant populations.

The planting machinery is usually critically important in crop establishment. Planting machines modify the pre-existing seed and soil conditions, and dictate seed placement within the seedbed. The pre-existing conditions can be improved or impaired as a result. An essential requirement of effective machinery management is to identify the main components of these machine-soil-seed interactions.

\section{Materials and Methods}

\section{Design Considerations}

The self-propelled groundnut planter was designed as a functional and experimental unit. The design of machine components were based on the principles of operations, tested and compared with the conventional method, to give a correct shape in form of prototype. The mechanical design details were also given with due attention so, as to give adequate functional rigidity for the design of machine.

\section{Planter}

Planter is sowing equipment used for sowing of bigger seeds. Row to row and plant to plant spacing is maintained in a planter.

\section{Selection of materials for planter}

Selection of proper materials for the manufacture of various components of planter is very important. Table 1 given the specifications of the materials for different components of a groundnut planter:

The cost and quality of planter depends on several factors, among which are the cost of materials, the accuracy of the finished parts and the quality of workmanship.

\section{Design of Planter Hoppers for Groundnut and Fertilizer}

\section{Capacity of hopper}

Box capacity is calculated based on the quantity of the material to be filled in the box at a given bulk density (Varshney et al., (2004).

Let, $\mathrm{V}=$ volume of box, $\mathrm{m}^{3}$

$\rho=$ bulk density of material, $\mathrm{kg} / \mathrm{m}^{3}=413.31$ $\mathrm{kg} / \mathrm{m}^{3}$

$\mathrm{Q}=$ box capacity, $\mathrm{kg}=7.5 \mathrm{~kg}(2.5 \mathrm{~kg}$ for each furrow)

Then $\mathrm{V}=\mathrm{Q} / \mathrm{\rho}$--- (1)

$=7.5 \div 413.31=0.018155 \mathrm{~m}^{3}=18155 \mathrm{~cm}^{3}$

And $\mathrm{V}=\mathrm{A} \times 1$

So $\mathrm{A}=\mathrm{V} \div 1$--- (2)

$=18155 \div(15 \times 3)=403.4 \mathrm{~cm}^{2}$

The cross section of box was divided in to two sections viz. $\mathrm{X}$ and $\mathrm{Y}$ (Fig. 1).

Section $\mathrm{X}$ is rectangular and section $\mathrm{Y}$ is trapezoidal

Cross sectional area of section $\mathrm{X}=\mathrm{a} \mathrm{x} \mathrm{b}$

Assume $\mathrm{a}=10 \mathrm{~cm}$ and $\mathrm{b}=30 \mathrm{~cm}$

So, area of $X=10 \times 30=300 \mathrm{~cm}^{2}$ 
Cross sectional area of section Y

$\mathrm{Y}=\mathrm{h}(\mathrm{B}+\mathrm{h} \cot \alpha)$

Where,

$\mathrm{h}=$ height of trapezoidal section, $\mathrm{cm}$;

$\mathrm{B}=$ base width of trapezoidal section, $\mathrm{cm}$; and

$\propto=$ angle of slope, degree.

$\mathrm{Y}=403.4-300=103.4 \mathrm{~cm}^{2}$

Assume base width of the box $=10 \mathrm{~cm}$ and angle of repose for groundnut seed in GI sheet ranges from 35 to $42^{\circ}$, therefore $\propto$ is taken as $45^{\circ}$

So, $103.4=h(10+h \cot 45)$

$\mathrm{h}=9.4 \approx 10 \mathrm{~cm}$

Therefore, the dimensions of the trapezoidal section were taken for base, top width and height was 10, 30 and $10 \mathrm{~cm}$ respectively.

\section{Design of seed metering devices}

A metering device draws seed from bulk and delivers them at the desired rates in the seed tubes for sowing in soil, uniformly. The device should not cause mechanical damage to seeds.

Metering devices used on planters may be vertical cell plate, horizontal cell plate, inclined cell plate, vertical rotor with repelled roller, belt with cells, cup or spoon type picking device, vacuum type seed pickers or pneumatic planter with seed plate For development of groundnut planter in the present study were taken as shown in Figure 2 , type feeding system was taken round cup type. Vertical plate cup or spoon type picking device was taken as metering device in groundnut planter. As per recommendation
(Veeramani and Subramanyam, 2011) for plant to plant spacing is $10 \mathrm{~cm}$; the ground wheel diameter was taken $38.18 \mathrm{~cm}$ that can be given the circumference of the ground wheel is $120 \mathrm{~cm}$.

It has been design that the top width of and the total height of seed box is 30 and $20 \mathrm{~cm}$ respectively. According to the dimension of seed box, $20 \mathrm{~cm}$ diameter(d) was taken for vertical plate of metering device, and clearance for welding of base of spoons was taken as $0.8 \mathrm{~cm}$. So, effective diameter $\left(\mathrm{d}_{\mathrm{e}}\right)$ of vertical plate was obtained $19.2 \mathrm{~cm}$.

The circumference $(\mathrm{P})$ of the vertical plate is calculated as

$\mathrm{P}=\pi \mathrm{d}_{\mathrm{e}}---(4)$

$\mathrm{P}=3.14 \times 19.2=60.3 \approx 60 \mathrm{~cm}$

Therefore, the periferal distance between two spoons $\left(\mathrm{d}_{\text {spoon }}\right)=\mathrm{P} \div \mathrm{n}=60 \div 12=5 \mathrm{~cm}$

The spoon were fitted on a vertical metal plate by a strip of round metal having thickness of $0.3 \mathrm{~cm}$ and width of $0.5 \mathrm{~cm}$.

\section{Design of fertilizer metering devices}

Non-uniform pressure distribution and frictional forces among fertilizer granules result in bridging. Agitators are used to overcome the bridging.

The orifice diameter was taken as $12 \mathrm{~mm}>$ $10.1 \mathrm{~mm}$ in the present design for metering of fertilizer. Additional arrangement was given to calibrate the fertilizer by sliding arrangement of plates just below the hole.

A spur gear (Fig. 3) having 12 grooves (as number of spoon on the groundnut metering mechanism was 12) with following specification was taken in the present design. 


\section{Seed delivery tubes}

Seeds fall freely from the feed cup through the tube into the furrow. Uniform seed to seed spacing was achieved when all seeds are released by the metering device from the same height with the same velocity. In a multi-row machine, the seed tubes should be adjustable for height. In present design spiral tubes made from PVC strip was taken for less damage of seed as it was highly flexible and could be adjusted for height of furrow openers.

\section{Design of tine of the furrow opener}

The minimum clearance $\mathrm{H}_{1}$ between the land surface and the lower edge of the frame should be $200 \mathrm{~mm}$. Figure 4 shows dimensions and forces acting on the furrow opener.

The height of tine $(\mathrm{H})$ of furrow opener was calculated as (Varshney, et al., 2004)

$H=a_{\max }+H_{1}+\Delta H--(5)$

Where,

$\mathrm{a}_{\max }=$ depth of tool $=11.5 \mathrm{~cm}$

$\mathrm{H}_{1}=$ length of tine $=20.0 \mathrm{~cm}$

$\Delta \mathrm{H}=$ length of tine used for fastening with frame $=4.0 \mathrm{~cm}$

So, $\mathrm{H}=11.5+20.0+4.0$

$\mathrm{H}=35.5 \mathrm{~cm}$

The tine of the furrow opener was exposed first of all to bending in consequence of soil resistance. The soil resistance $\left(\mathrm{F}_{\mathrm{x}}\right)$ is horizontal and acts in the axis of symmetry of shoe. The value of the actual average soil resistance is obtained by the formula:
$F_{x}=a \times W_{w} \times P_{k} \ldots \ldots(6)$

Where,

$\mathrm{a}=$ Effective working depth of tine $=10 \mathrm{~cm}$

$\mathrm{W}_{\mathrm{w}}=$ Effective working width of tine $=5 \mathrm{~cm}$

$\mathrm{P}_{\mathrm{k}}=$ Specific soil resistance for the medium soil

Specific soil resistance $\mathrm{P}_{\mathrm{k}}$ when sowing to a depth of $15 \mathrm{~cm}$ under different soils are:

Light soil: $0.12 \mathrm{~kg} / \mathrm{cm}^{2}$

Medium soil: $0.15 \mathrm{~kg} / \mathrm{cm}^{2}$

Heavy soil: $0.20 \mathrm{~kg} / \mathrm{cm}^{2}$

Very heavy soil: $0.35 \mathrm{~kg} / \mathrm{cm}^{2}$

Therefore,

$\mathrm{F}_{\mathrm{x}}=10 \times 5 \times 0.35=17.5 \mathrm{~kg}$

Draft at the tip of tine $\left(D_{t}\right)=17.5 \mathrm{~kg}$

Total draft $=17.5 \times 3=52.5 \mathrm{~kg}$

Stress $(\sigma)$, causing the tine to bend was calculated as:

$\sigma=\frac{6 D_{t}\left(H_{1}+a\right)}{t h^{2}}$

Where,

$\mathrm{D}_{\mathrm{t}}=$ draft at the tip of tine, $\mathrm{kg}$;

$\mathrm{H}_{1}=$ length of tyne, $\mathrm{cm}$;

$\mathrm{a}=$ Effective working depth of tine, $\mathrm{cm}$;

$\mathrm{t}=$ thickness of the tyne, $\mathrm{cm}$ and

$\mathrm{h}=$ width of tine, $\mathrm{cm}$

It is to be assumed that the thickness ( $\mathrm{t}$ ) and width (h) of tine were 1.0 and $4.0 \mathrm{~cm}$ respectively,

$$
\begin{aligned}
& \sigma=\frac{6 \times 22.5(20+10)}{1 \times(4)^{2}} \\
& \sigma=253.12 \mathrm{~kg} / \mathrm{cm}^{2}
\end{aligned}
$$


Now, Torsional stress $(\tau)$ is calculated as:

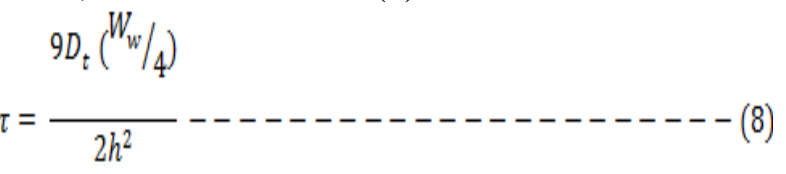

Where,

$\mathrm{W}_{\mathrm{w}}=$ Effective working width of tine, cm; and

$\mathrm{h}=$ width of tine, $\mathrm{cm}$

$\tau=\frac{9 \times 22.5(5 / 4)}{2 \times 4^{2}}$

$\tau=7.91 \mathrm{~kg} / \mathrm{cm}^{2}$

Then, the reduced stress was calculated as:

$\delta=\sqrt{\sigma^{2}+4 \tau^{2}}$

Where,

$\delta=$ reduced stress, $\mathrm{kg} / \mathrm{cm}^{2}$

$\sigma=$ stress, $\mathrm{kg} / \mathrm{cm}^{2} ;$ and

$\tau=$ Torsional stress, $\mathrm{kg} / \mathrm{cm}^{2}$

$\delta=\sqrt{(253.12)^{2}+4 \times(7.91)^{2}}$

$\delta=253.61 \mathrm{~kg} / \mathrm{cm}^{2}$

The factor of safety has been taken 5 times more than that of the actual stress,

Therefore, the stress $=253.61 \times 5=1268.05$ $\mathrm{kg} / \mathrm{cm}^{2}$

The allowable stress of spring steel is 1362.00 $\mathrm{kg} / \mathrm{cm}^{2}$ which are more than the designed stress 1268.05. There was a provision of four holes of $10 \mathrm{~mm}$ diameter each at equal distance for lowering tine upto a depth of 8 cm (Fig. 4).

\section{Design of frame}

The components of the groundnut planter are mounted on the main frame (chassis) which is supported by two gauge wheels. The machine is also connected to the rigid hitch point of the prime-mover. The design should be based on the stresses produced on the front of frame (Lal and Dutta, 1995).

Draft required per tyne $\left(D_{t}\right)=22.5 \mathrm{~kg}$ (already calculated)

Total torque on the front of frame $(\mathrm{T})=3 \mathrm{x}$ $22.5 \times 45=3037.5 \mathrm{~kg}-\mathrm{cm}$

In addition to the torque, bending will also produced on frame. The frame can be taken as simply supported beam in between the two gauge wheel.

$\mathrm{R}_{\mathrm{x}}=(22.5 \times 3) \div 2=33.75 \mathrm{~kg}$

$\mathrm{W}=$ weight of seed box, fertilizer box with full of fertilizer and seed $=35 \mathrm{~kg}(\max )$ and assumed to be act at the centre of the tool bar.

Hence,

Maximum bending moment on the centre

$M=(33.75 \times 45)+(35 \times 45)-(22.5 \times 30)$

$=2418.75 \mathrm{~kg}-\mathrm{cm}$

So,

Equivalent toque $\left(\mathrm{T}_{\mathrm{e}}\right)=\sqrt{\mathrm{M}^{2}+\mathrm{T}^{2}}$ $---(10)$

$=\sqrt{2418.75^{2}+3037.5^{2}}=3882.88 \mathrm{~kg}-\mathrm{cm}$.

\section{Design of depth control-cum-transport wheel}

Two depth control of $25 \mathrm{~cm}$ diameter made out of $4.0 \mathrm{~cm} \times 0.5 \mathrm{~cm}$ flat and $4 \mathrm{~cm}$ diameter spokes were fitted at the axle of the transport wheel (Fig. 7).

The diameter of the shaft was kept at 1.20. A shaft of 1.20 diameter supported by a square section $(45 \mathrm{~cm} \times 4 \mathrm{~cm} \times 4 \mathrm{~cm})$ attached the 
wheel in perpendicular direction, which was also used for lowering the machine to a proper depth as required. It can be lower up to $1.5 \mathrm{~cm}$ as and when required. When the transport wheel was lifted up to $12 \mathrm{~cm}$ it gave the exact desirable depth of sowing for groundnut. Hence, a marker has been provided for efficient placement of seed.

\section{Design of power transmission system}

The power is transmitted through the drive wheel to the seed metering device and fertilizer metering device with the help of two set of chain and sprocket mechanism for the accurate power transmission as shown in the Figure 8. Here the power comes from the drive wheel, it drives the idler gear then the idler gear transmit the power to the shaft of seed and fertilizer metering device simultaneously. The gear ratio of ground wheel, seed metering unit and fertilizer metering unit was calculated as:

$\frac{N_{1}}{N_{2}}=\frac{N_{2}}{N_{3}}=\frac{N_{3}}{N_{4}}=\frac{N_{4}}{N_{5}}$

$\mathrm{N} 1$ = Number of teeth in gear of ground wheel $=18$;

$\mathrm{N} 2=$ Number of teeth in first follower gear $=$ 18 ;

N3 = Number of teeth in second follower gear $=18$;

N4 = no of teeth in gear of seed metering device $=18$; and

N5 = Number of teeth in gear of fertilizer metering device $=18$.

$\frac{18}{18}=\frac{18}{18}=\frac{18}{18}=\frac{18}{18}$

Thus the gear ratio was 1:1 for the whole metering assembly. The number of revolution per minute of the ground wheel was same as that of number of revolution per minute in the seed and fertilizer metering unit.

\section{Design of chain}

The chains are mostly used to transmit motion and power from one shaft to another, when the centre distance between the shafts is short.

In order to obtain a constant velocity ratio, chain drive is mostly preferred.

The length of first chain (L) attached from ground wheel to $1^{\text {st }}$ idler sprocket was calculated as (Shah and Jadvani, 1990):

$L=p\left[\frac{n_{1}+n_{2}}{2}+\frac{\left(\operatorname{cosec} \frac{180^{\circ}}{n_{3}}+\operatorname{cosec} \frac{180^{\circ}}{n_{2}}\right)^{2}}{4 m}+2 m\right]$

Where,

$\mathrm{p}=$ Pitch length i. e. $1.3 \mathrm{~cm}$

$\mathrm{n}_{1}=$ Number of teeth on bigger sprocket i.e. 18

$\mathrm{n}_{2}=$ Number of teeth on smaller sprocket i. e. 18

$\mathrm{C}=$ Distance between centre of two sprockets i.e. $41.80 \mathrm{~cm}$

$\mathrm{m}=\mathrm{C} / \mathrm{p}=41.80 / 1.3=32.15$

Length of the first chain $=$

$L=1.3\left[\frac{18+18}{2}+\frac{\left(\operatorname{cosec} \frac{180^{\circ}}{18}+\operatorname{cosec} \frac{180^{\circ}}{18}\right)^{2}}{4 \times 32.15}+2 \times 32.15\right]$

$=1.3 \times 82.39=107.11 \mathrm{~cm} \approx 107 \mathrm{~cm}$

Length of second set chain attached from idler to seed and fertilizer unit

Length of chain for the second set of chain 
and sprocket was calculated as:

$\mathrm{L}=\mathrm{p}+\mathrm{q}+\mathrm{r}+\pi \mathrm{d}---(12)$

Where,

$\mathrm{L}=$ Length of chain, $\mathrm{cm}$;

$\mathrm{p}=$ distance between the sprocket of seed and fertilizer unit i.e. $24.3 \mathrm{~cm}$;

$\mathrm{q}=$ distance between the sprocket of seed and idler i.e. $16.6 \mathrm{~cm}$;

$\mathrm{r}=$ distance between the sprocket of fertilizer unit and idler i.e. $30.50 \mathrm{~cm}$; and $\mathrm{d}=$ diameter of pitch circle i.e. $7 \mathrm{~cm}$ hence,
$\mathrm{L}=24.3+16.6+30.5+3.14 \times 7.0=93.3 \mathrm{~cm}$ $\approx 94 \mathrm{~cm}$

\section{Results and Discussions}

The ground nut planter was designed and developed. An attempt was made for mounting of ground nut planter to the power weeder which is available at College of Agricultural Engineering, Madakasira. The basic idea for mounting of groundnut planter to the power weeder is "the negative draft generation of the power weeder helps to reduce the positive draft requirement of groundnut planter".

Fig.1 Cross section of seed box

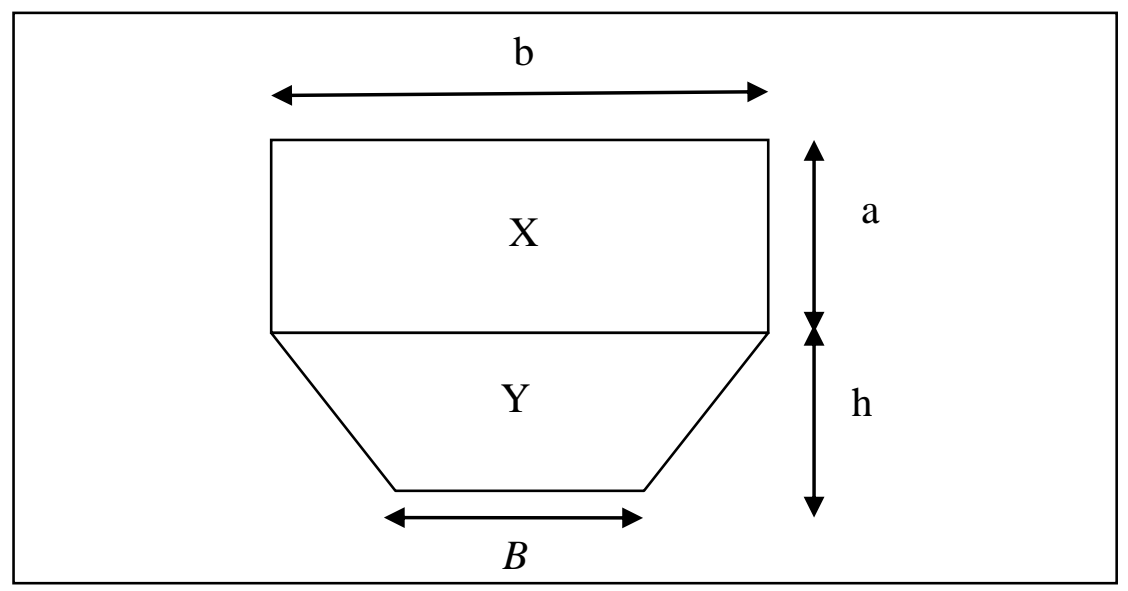

Fig.2 Vertical plate cup feed metering devices

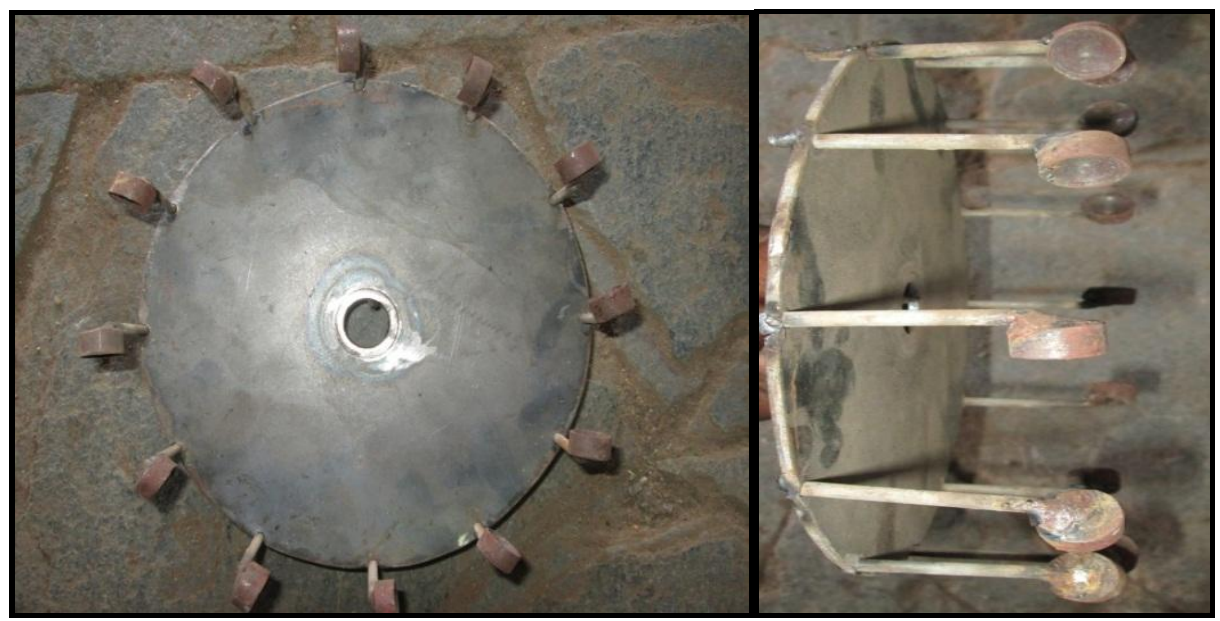


Fig.3 Spur gear with orifice used for fertilizer metering mechanism

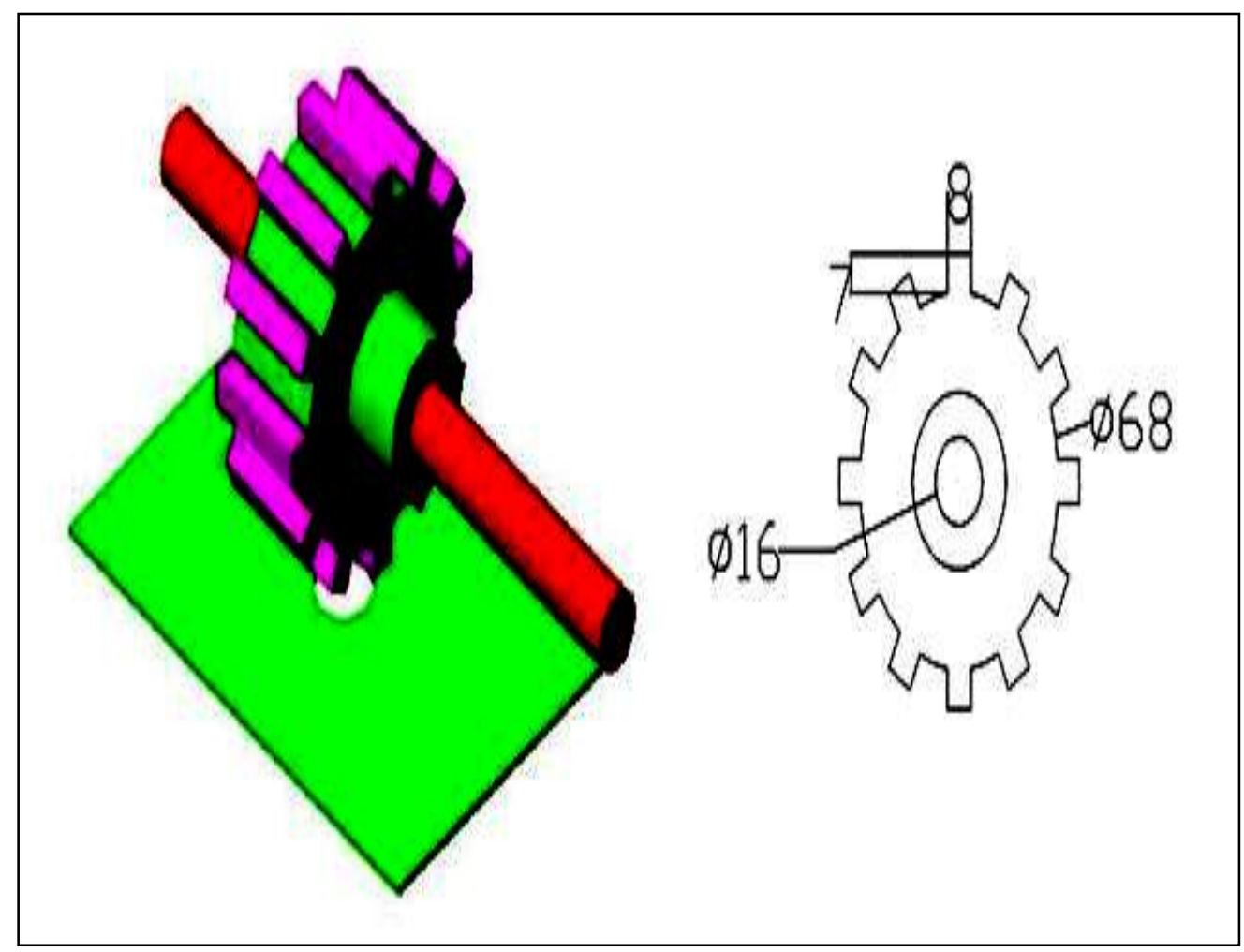

Fig.4 Showing different dimensions and forces acting on the furrow opener and tines

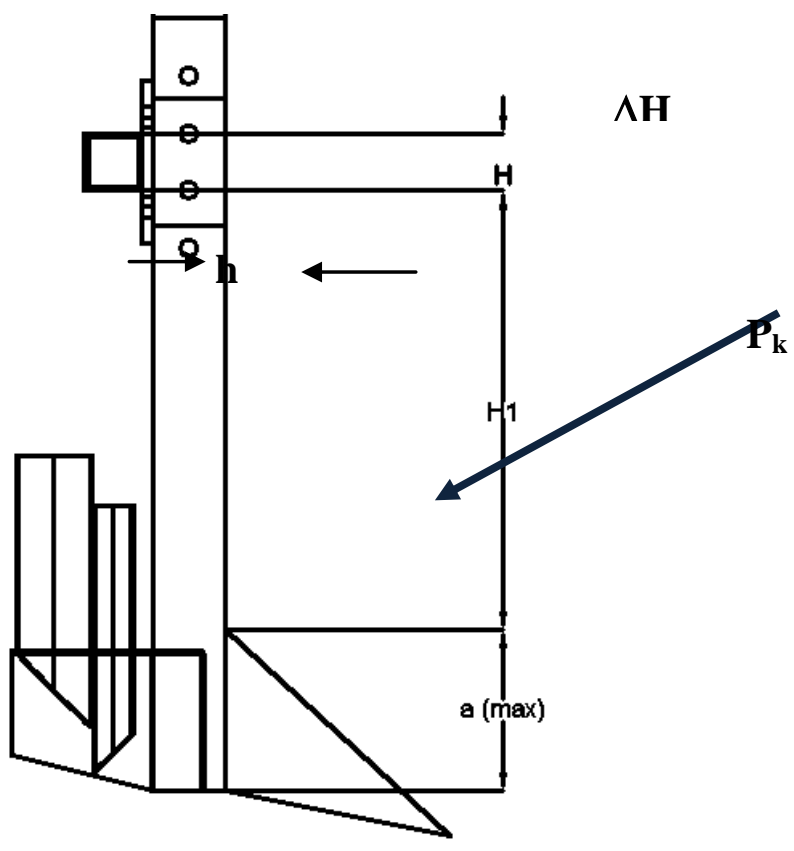


Fig.5 Tine of furrow opener (a) Front view (b) Isometric view

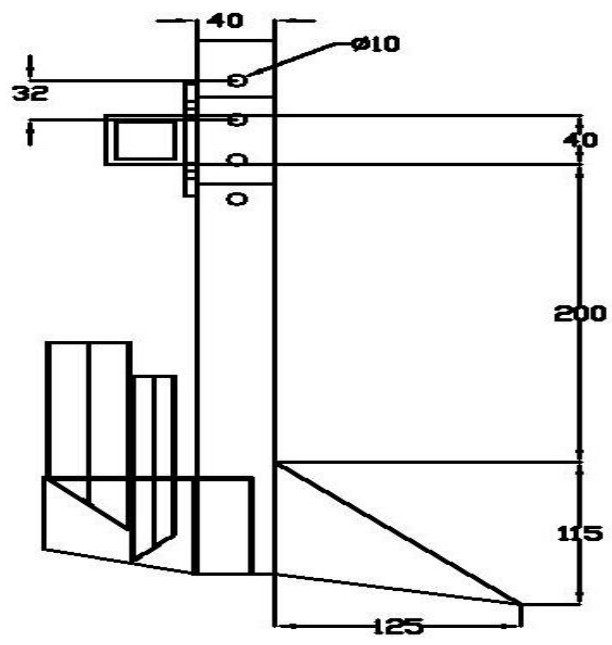

Front view

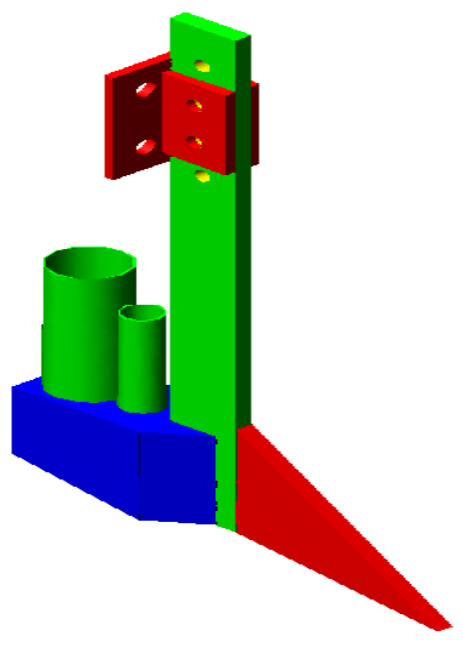

Isometric view

All dimensions are in $\mathrm{mm}$

Fig.6 Arrangement of tines on the frame and direction of forces action on it

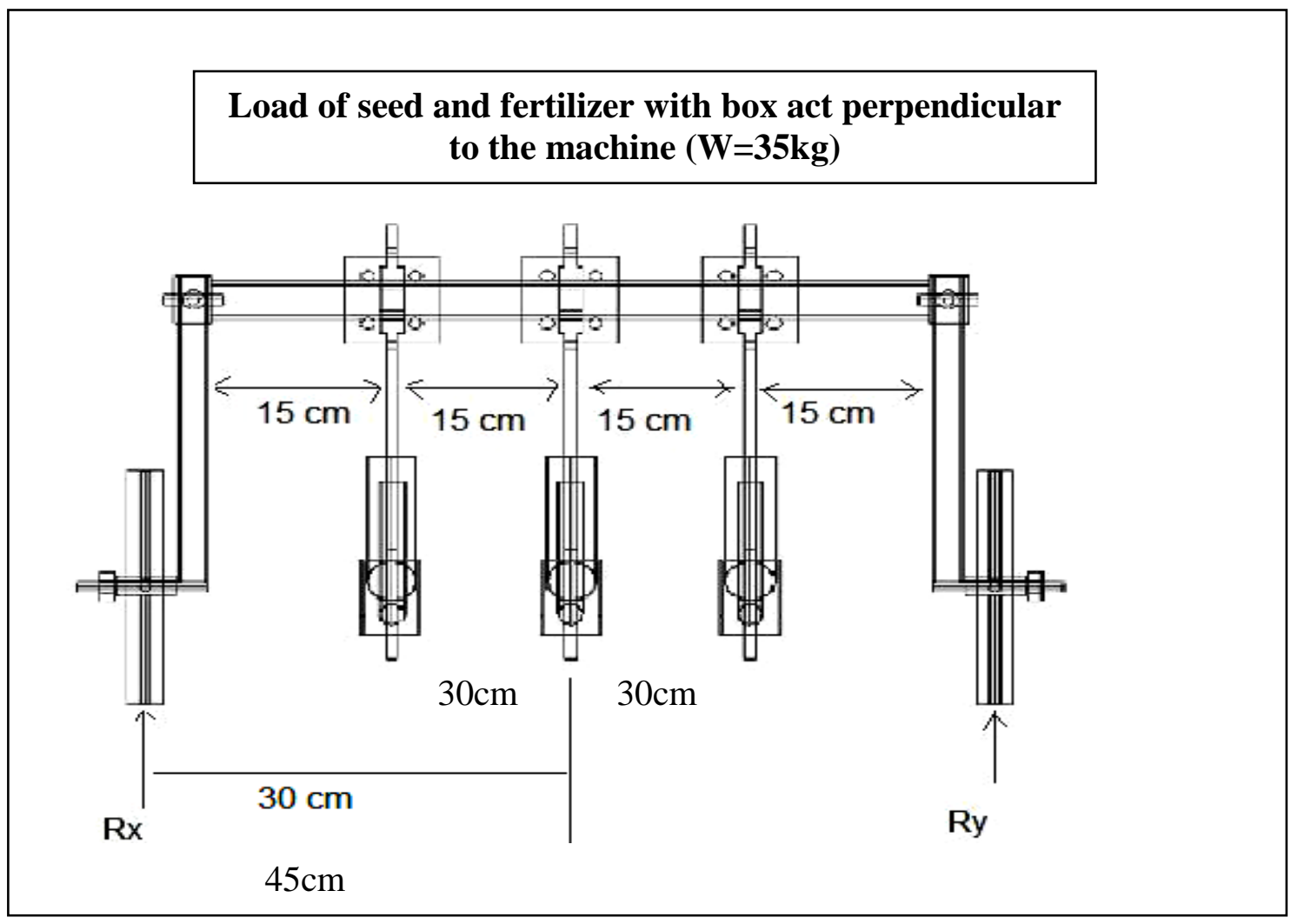


Fig.7 Details of the transport wheel, (a) Front view, (b) Top view (c) isometric view

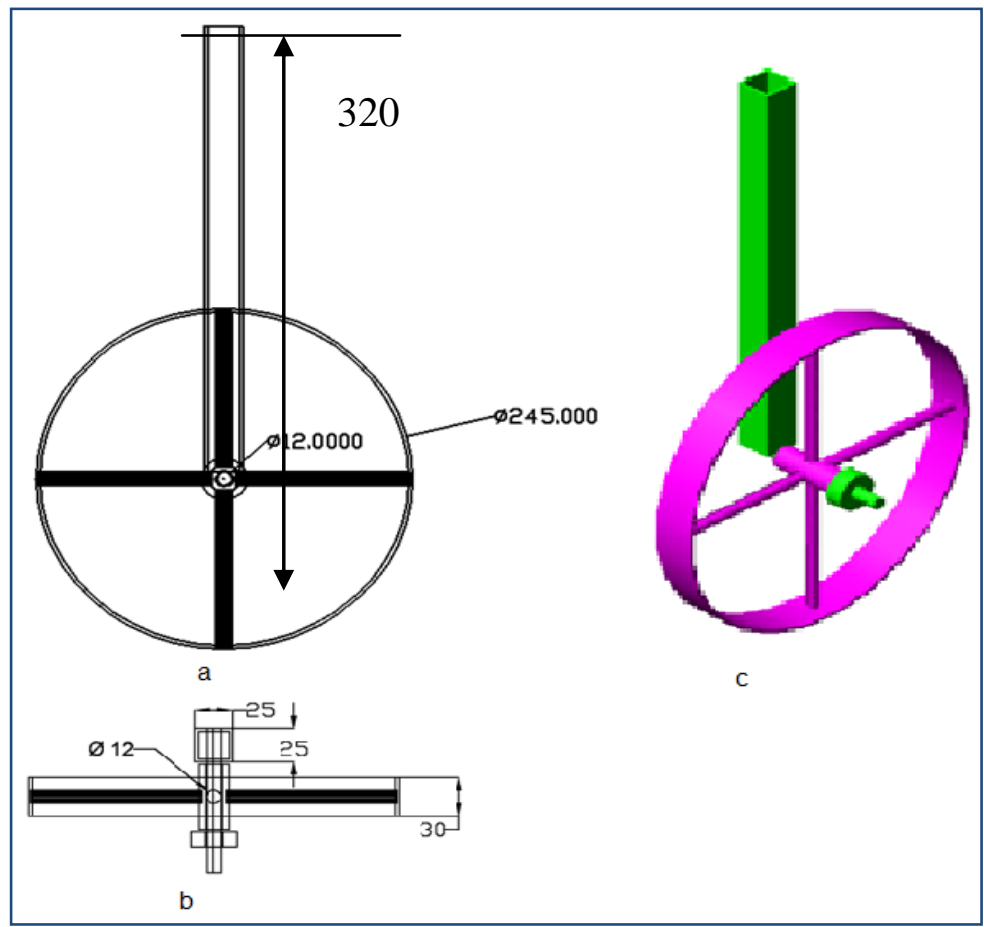

Fig.8 Complete driving system attached in the groundnut planter for transmission of power from ground wheel

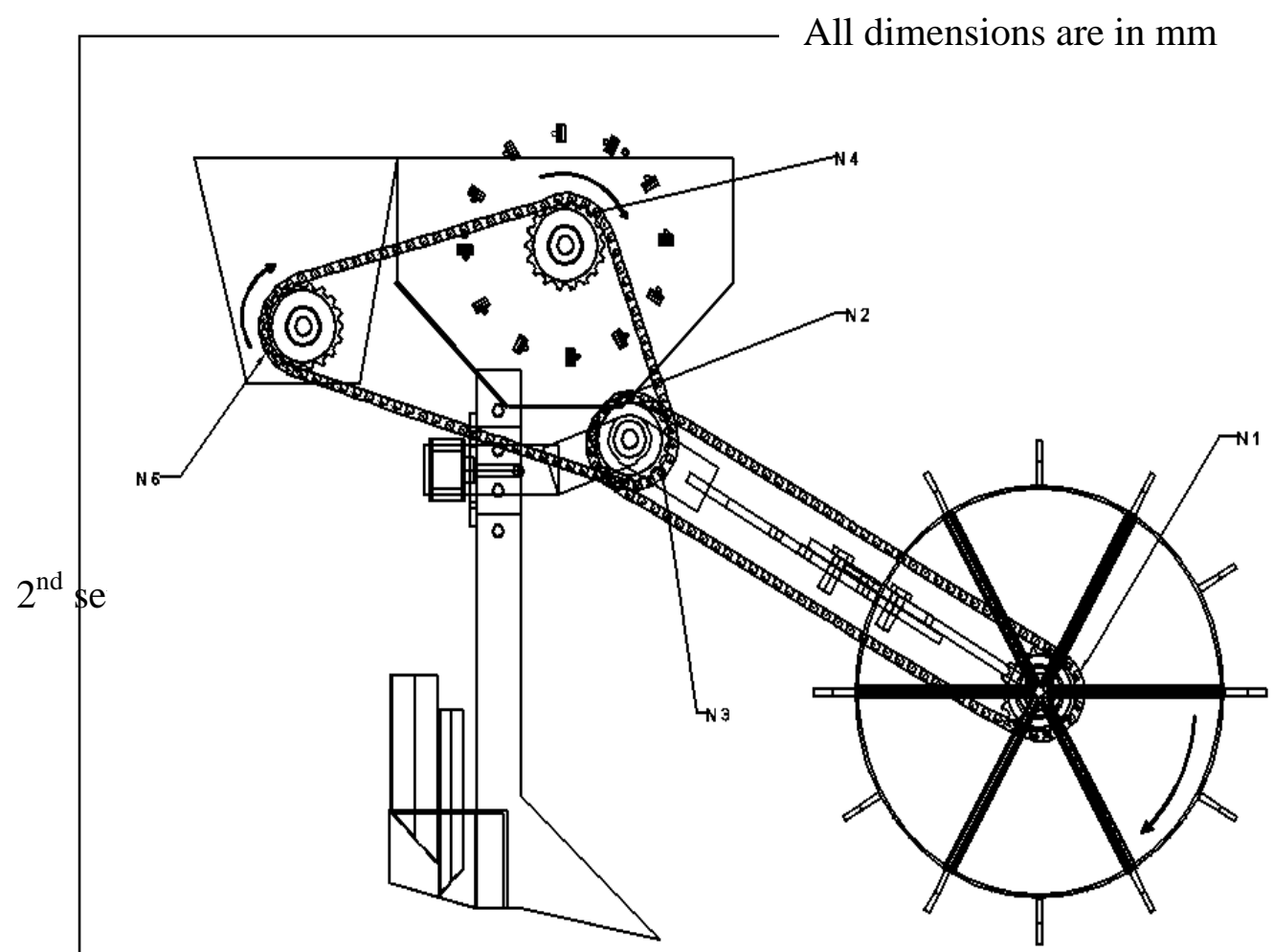


Fig.9 Design of second set of chain attaching idler sprocket to seed and fertilizer

\section{All dimensions are in $\mathrm{mm}$}

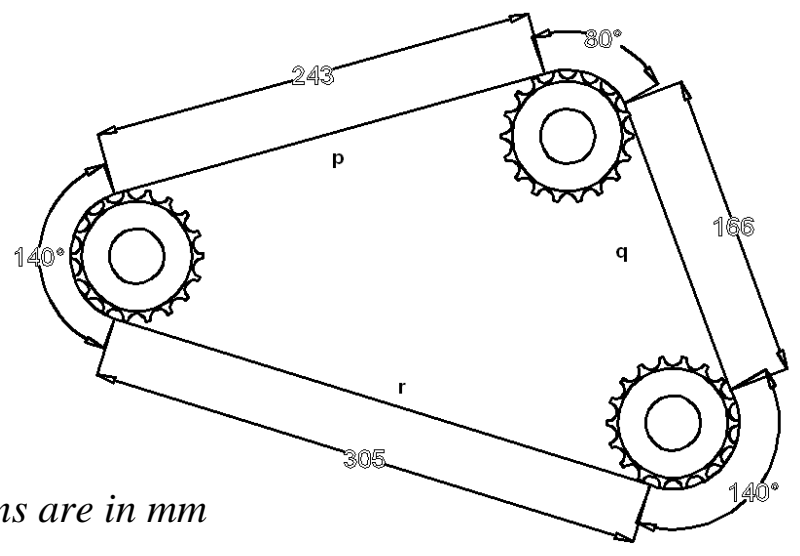

Fig.10 Attaching of groundnut planter to the power weeder

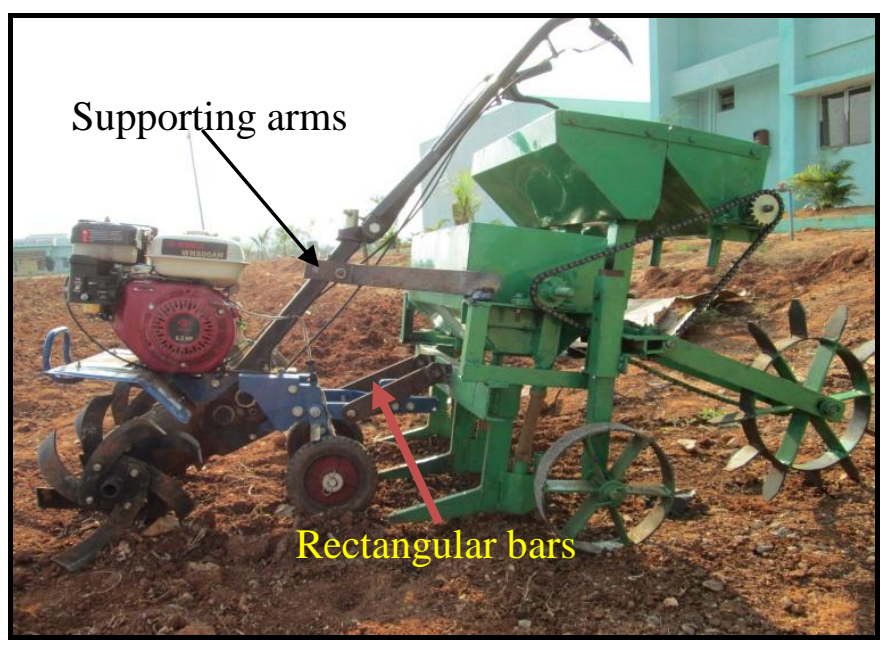

Table.1 Selection of material for Groundnut planter

\begin{tabular}{|l|l|l|l|}
\hline S. No. & Parts & Material specifications & Size \\
\hline 1. & Seed box & Hot rolled black sheet & $1.0 \mathrm{~mm}$ thick \\
\hline 2. & Fertilizer box & M.S. cold rolled sheet used at base & $2.0 \mathrm{~mm}$ thick \\
\hline 3. & Vertical cup feed type metering devices & High grade cast iron with gun metal bushed & $2.0 \mathrm{~mm}$ thick \\
\hline 4. & Roller with spoon & Round bars of mild steel & $4.0 \mathrm{~mm}$ thick and $50 \mathrm{~mm}$ long \\
\hline 5. & Orifice plates & Cold rolled mild steel sheets & $2.0 \mathrm{~mm}$ thick \\
\hline 6. & Seed tubes & Polyethylene tubes & $40 \mathrm{~mm}$ diameter, $2 \mathrm{~mm}$ thick, transparent \\
\hline 7. & Fertilizer tubes & $\begin{array}{l}\text { Medium carbon steel-heat treated to shovel hardness of } \\
\text { RC }-40 / 45\end{array}$ & $20 \mathrm{~mm}$ diameter, $2 \mathrm{~mm}$ thick, transparent \\
\hline 8. & Furrow openers & Cold rolled M.S. sheet & $3 \mathrm{~mm}$ thickness \\
\hline 9. & Opener boots & Cot forged MS flate & $10 \mathrm{~mm}$ thick \\
\hline 10. & Opener tynes & M.S. flat & $20 \mathrm{~mm}$ thick \\
\hline 11. & Shaft for seed metering & M.S. square section pipes & $5 \mathrm{~mm}$ thick \\
\hline 12. & Ground wheel & $\begin{array}{l}\text { Roller chains, sprockets (Sheet punched), split pins, } \\
\text { hex head bolts and nuts plain and spring washers, etc. }\end{array}$ & $4 \mathrm{~mm}$ thick \\
\hline 13. & Main frame and fitches & \\
\hline 14. & Standard finished items &
\end{tabular}


be as per standard, used in light engineering industry.

The groundnut planter was mounted to power weeder with the help of two supporting arms at the middle of the machine which are for supporting the load as well as distribution of load and two rectangular bars at the bottom on either side of the machine for stability as well as for pulling the planter under transport and field conditions as shown in Fig. 10.

The designed and developed groundnut planter for power weeder was tested at research farm of College of Agricultural Engineering, Madakasira. A $10 \mathrm{~m}$ x $10 \mathrm{~m}$ plot was selected for evaluation of the power weeder drawn ground nut planter. The ground nut seeds were placed inside the hopper about half of its capacity and the machine were operated at the forward speed of $1.5 \mathrm{kmph}$ on unploughed land. The plant to plant spacing was measured at different locations in the selected plot. It was observed that, the spacing between two plants is $10 \mathrm{~cm}$ at different locations, but in some places, the spacing is ranges from $10 \mathrm{~cm}$ to $12 \mathrm{~cm}$, it may be due to seed movement in the furrow. Also it was observed that, the metering mechanism was dropping mostly one seed only; in some places it was observed two seeds, the reason was because of small size of seeds (length is greater than the width) more seeds are occupying the seed metering cup.

The row to row spacing was also measured at different locations; it was observed that $30 \mathrm{~cm}$ spacing between two rows throughout the field. A provision was made for increasing or decreasing the row to row spacing by adjusting the U- clamp holder of tines. It was also observed that the seeds are dropping exactly at the centre of the furrow throughout the field also all the rows are in straight line under field. The depth and width of furrow opener was measured under field condition. It was observed that, the average width and depth of furrow opener was $10 \mathrm{~cm}$ and $5 \mathrm{~cm}$ respectively for entire row. The provision was made for changing of depth of operation by adjusting the height of furrow opener also the height of land wheel.

\section{$\operatorname{Draft}\left(\mathbf{F}_{\mathrm{x}}\right)$}

The horizontal component of resultant force required topull a machine in the field is draft. The draft requirement of the machine was calculated by the following formula

$F_{x}=a \times W_{w} \times P_{k}$

Where,

$\mathrm{a}=$ Effective working depth of tine $=10 \mathrm{~cm}$

$\mathrm{W}_{\mathrm{w}}=$ Effective working width of tine $=5 \mathrm{~cm}$

$\mathrm{P}_{\mathrm{k}}=$ Specific soil resistance for the medium soil

The draft requirement for pulling of the ground nut planter was $52.5 \mathrm{~kg}$

Developed power weeder drawn groundnut planter consists of one ground wheels of diameter $38.12 \mathrm{~cm}$, three no. of plates provided mounted on the rotating shaft. The entire attachment was fixed on the frame. Ground wheel rotates the power transmit with the suitable gears and chain and rotate metering unit (3 plates) with attached spoons. Total length of the machine $1.2 \mathrm{~m}$ and width is $90 \mathrm{~cm}$.

The developed power weeder drawn groundnut planter was field tested in red soil in the experimental plot at College of Agricultural Engineering, Madakasira. The field area length $10 \mathrm{~m}$ and width of $10 \mathrm{~m}$. No. of seeds in a square meter, plant to plant spacing $10 \mathrm{~cm}$ and row to row spacing $30 \mathrm{~cm}$ were replicated 5 times.

\section{References}


Ashok, B., Jayanthiand G.M. Prashantha., 2012. Performance evaluation of power drawn six row groundnut planterInternational journals of agricultural engineering, vol 5 (issue 2). October, 2012 (123-126).

Jagdeshwar Sahay, Elements of Agricultural Engineering, Fourth edition- 2010 (Reprint).

Jarudchai Yenpayub, 2006. Design and development of a garlic planter in Thailand. Journal of Agricultural Engineering Research, 15(5): 17-22.

Lal, R., and A. C. Dutta 1995. Agricultural Engineering (through worked examples), Saroj Prakasan, Allahabad.

Madhusudhana, 2010. A Survey on Area, Production and Productivity of
Groundnut Crop in India. IOSR Journal of Economics and Finance (IOSR-JEF) e-ISSN: 2321-5933, p-ISSN: 23215925. Volume (1).

Varshney, A. C., Kumar, U. and Naik, R. K. 2004. Sowing and planting equipment, Book for Agricultural machine Design, CIAE/2004/01, pp: 210-245.

Virmani, S.M., and Shurpali, N.J. 1999. Climate prediction for sustainable production of rainfed groundnuts in SAT: crop establishment risks in groundnut production in the Anantapur region. Technical Manual no. 4. Patancheru 502 324, Andhra Pradesh, India: International Crops Research Institute for the Semi-Arid Tropics.

\section{How to cite this article:}

Anil Kumar, A., Ch. Ramulu, B. Laxman and Kishore, G. 2017. Design and Development of Groundnut Planter for Power Weeder. Int.J.Curr.Microbiol.App.Sci. 6(10): 3516-3528. doi: https://doi.org/10.20546/ijcmas.2017.610.415 